Avrupa Bilim ve Teknoloji Dergisi

Özel Sayı, S. 398-403, Ekim 2019

(C) Telif hakkı EJOSAT'a aittir

Arassturma Makalesi
European Journal of Science and Technology

Special Issue, pp. 398-403, October 2019

Copyright (C) 2019 EJOSAT

$\underline{\text { Research Article }}$

\title{
Design of a Mini Fluorescence Microscope
}

\author{
Mehmet Yüksekkaya $^{1 *}$, Buket Şahin ${ }^{2}$, Gülnihal Özel ${ }^{3}$ \\ ${ }^{1}$ Başkent University, Engineering Faculty, Biomedical Engineering Department, Ankara, Turkey (ORCID: 0000-0002-2665-5799) \\ ${ }^{2}$ Başkent University, Engineering Faculty, Biomedical Engineering Department, Ankara, Turkey (ORCID: 0000-0001-9535-9363) \\ ${ }^{3}$ Başkent University, Engineering Faculty, Biomedical Engineering Department, Ankara, Turkey (ORCID: 0000-0002-8503-2321)
}

(This publication has been presented orally at "International Congress on Human-Computer Interaction, Optimization and Robotic Applications (HORA) July 5-7, 2019, Urgup, Nevsehir, Turkey" congress.)

(First received 01.08.2019 and in final form 25.10.2019)

(DOI: 10.31590/ejosat.638369)

ATIF/REFERENCE: Yüksekkaya M., Şahin B. \& Özel G. (2019). Design of a Mini Fluorescence Microscope. European Journal of Science and Technology, (Special Issue), 398-403.

\begin{abstract}
Microscopy is one of the most commonly used imaging methods in scientific research. The fluorescence microscopes which are used to determine the cell and tissue content at the molecular level, provides high-resolution images of the fluorochrome marked molecules. They are used in many areas with this feature. However, the use of fluorescence microscopy in biomedical field is limited due to various factors such as cost, size and difficulty of use. Also for some applications of fluorescence microscopy there are no need for very high quality and detailed images. Therefore, a small, practical and cost-effective mini fluorescent microscope is needed (Sanz, Picazo-Bueno, Granero, \& Micó, 2017).

In this study, a practical, portable and cost-effective fluorescent microscope was designed for specific proposes. Unlike the common fluorescent microscopes in this mini version one emission and one excitation wavelength is used. From top to bottom the design consists of a LED which is emitting the chosen wavelength of light, an excitation filter that can be used if necessary, a sample holder, a practical focus system developed in this project to be used for focus adjustment, a single-focus microscope objective lens, an emission filter and a camera. Plates holding these elements were formed using laser cutter, these plates are fixed in the form of layers with the appropriate materials. Filters and LED light source were determined and supplied according to the specific fluorescent dye to be used. These elements were tested by spectrophotometer and assembled together in the design. The LED power driver used in the design was supplied and the connections with the LED are completed.

The focal point was calculated as $4 \mathrm{~mm}$ and the focal length as $44 \mathrm{~mm}$ so optical magnification $0.27 \mathrm{um} /$ pixel was obtained. This means a 610 times magnification on a 15.6-inch screen.

Using the mini fluorescent microscope a fluorochrome sensitive to $360 \mathrm{~nm}$ wavelength was imaged. And the image from emitted light at $460 \mathrm{~nm}$ wavelength was obtained. The entire design cost 2500 TL (434 USD). The dimensions of the fluorescence microscope are $120 \mathrm{~mm} \times 120 \mathrm{~mm} \times 170 \mathrm{~mm}, 2448 \mathrm{~cm}^{3}$. Its weight is $1 \mathrm{~kg}$.

This mini fluorescence microscope can be used as an alternative to traditional fluorescent microscopes in developing countries and geographies where resources are scarce, because it is cost-effective and portable. As it is practical and user friendly, it can reduce the need for expert person. Also for point of care applications, this microscope can be an alternative for conventional fluorescence microscopy.
\end{abstract}

Keywords: Fluorescence microscopy, fluorescence dye, spectrophotometer, laser cutter

\footnotetext{
* Corresponding Author: Başkent University, Department of Biomedical Engineering, Ankara, Turkey, ORCID: 0000-0002-2665-5799, mehmety@baskent.edu.tr
} 


\section{Mini Floresan Mikroskop Tasarımı}

\section{$\ddot{O ̈ z}$}

Mikroskopi, bilimsel araştırmalarda en çok kullanılan görüntüleme yöntemlerinden biridir. Moleküler düzeyde hücre ve doku içeriğinin belirlenmesinde kullanılan floresan mikroskop, hedef molekülü işaretleyerek mikroskop altında yüksek çözünürlükle görüntülenmesini sağlar. Bu özelliği ile birçok alanda kullanılırlar. Ancak biyomedikal alanında mikroskop kullanımı, maliyet, boyut ve kullanım kolaylığı gibi çeşitli faktörlerden dolayı sınırlıdır. Aynı zamanda floresan mikroskobunun kullanıldığı kaliteli ve ayrıntılı görüntüler gerektiren uygulamalar olmasına karşın, her uygulamada bu kadar ayrıntıya ihtiyaç duyulmaz. Bu nedenle küçük, pratik ve uygun maliyetli bir mini floresan mikroskoba ihtiyaç vardır.

Bu çalışmada özel uygulamalarda kullanılabilecek tek dalga boyunda uyarılabilen böylece tek dalga boyundaki yansımaları algılayarak görüntüleme yapabilecek, pratik, taşınabilir ve düşük maliyetli bir floresan mikroskop tasarımı gerçekleştirilmiştir. Tasarım sırası ile yukarıdan aşağıya doğru istenilen dalga boyunda ışı yayan bir LED, gerekli duyulması durumunda kullanılabilecek bir uyarım filtresi, örnek tutacağı, fokus ayarlamasında kullanılacak bu proje kapsamında geliştirilmiş pratik fokus sistemi, tek odaklı bir mikroskop objektifi, emisyon filtresi ve kameradan oluşmaktadır. Elemaları tutacak plakalar lazer kesici kullanılarak oluşturulmuş, bu plakalar katman şeklinde uygun malzemelerle sabitlenmiştir. Optik düzenekte kullanılacak floresan boyaya göre filtreler ve 1şık kaynağı belirlenmiş ve temin edilmiştir. Bu elemanlar spektrofotometre cihazı ile test edilerek tasarıma uygun şekilde bir araya getirilmiştir. Tasarımda kullanılan LED sürücüsü hazır olarak temin edilmiş, LED ile olan bağlantıları gerçekleştirilmiştir.

Odak noktası $4 \mathrm{~mm}$ ve odak uzaklığı $44 \mathrm{~mm}$ olacak şekilde hesaplanmış ve optik büyütme 0.27 um/piksel bulunmuştur. 15.6 inç bir ekranda bu büyütme 610 kat olur.

Tasarlanan mikroskop ile $360 \mathrm{~nm}$ dalgaboyuna duyarlı floresan boya görüntülenmiş ve $460 \mathrm{~nm}$ dalgaboyunda yaydığı görüntü alınmıştır. Tüm tasarım 2500 TL (434 USD)' ye mal olmuştur. Floresans mikroskopun boyutları $120 \mathrm{~mm}$ x $120 \mathrm{~mm}$ x $170 \mathrm{~mm}$ yani $2448 \mathrm{~cm}^{3}$ tür. Ağırlığı 1000 gramdır.

Tasarlanan mini floresan mikroskop, uygun maliyetli ve taşınabilir olduğu için kaynakları kısıtlı olan coğrafyalarda ve gelişmekte olan ülkelerde geleneksek floresans mikroskoplara göre özellikli uygulamalarda alternatif olabilir. Pratik ve kullanıcı dostu olduğu için uzman kişi ihtiyacını azaltabilir. Özellikle yerinde teşhis uygulamalar için geleneksek floresans mikroskoba bir alternatif olacaktır.

Anahtar Kelimeler: Floresan mikroskop, floresan boya, spektrofotometre, lazer kesici

\section{Introduction}

Fluorescence emerges as an electron stimulated to a higher and more unstable energy state, where the variable electron emits at a specific wavelength as it returns to the base level. The light responsible for the excitation or moving the electron to a higher energy state has a shorter wavelength and higher energy, because some energy is lost in this process. This principle is also used in fluorescence microscopes (Spring \& Davidson).

In fluorescent microscopes, the excitation light is filtered through the excitation filter from the light source and reflected through the dichroic mirror. Once the sample begins to emit fluorescence, this fluorescence returns through the same target and passes through the dichroic mirror. The system has an emission filter that only transmits fluorescent light and blocks any scattered excitation light. Thus, only the fluorescence emitted by the sample is displayed in the detector (eye, CCD camera) (Stuurman, 2012).

In the studies conducted so far, Zhang and his colleagues have designed a camera, led, and sample covering, and supported it with a perfusion system to observe live cell culture (Zhang \& Ribas, 2015). In another study, Aydogan Özcan and his colleagues observed the refraction of the laser light at an angle without using dichroic mirror (Wei, Tseng, \& Ozcan, 2013). This work has proven that it can be possible without using dichroic mirror.

In this project, a mini fluorescent microscope design aimed at low cost, single wavelength based, portable design and customizable use was carried out. In the analysis of a particular type of cell, it is aimed to provide faster and more accurate cell images, which are single focal points, stimulated by light at a single wavelength and which detect light at a single wavelength. For this purpose, after determining the materials suitable for the design, the designed mechanical frame was formed by using laser cutter. A mini fluorescent microscope was completed along with the design recommendations presented. The focal point for this microscope was calculated to be $4 \mathrm{~mm}$ and the focal length to be $44 \mathrm{~mm}$, and optical magnification was found to be $0.27 \mathrm{um} /$ pixel. Under the designed microscope, fluorescent dye sensitive to $360 \mathrm{~nm}$ wavelength was visualized and fluorescent particles emitted at $460 \mathrm{~nm}$ wavelength were observed.

\section{Material and Method}

\subsection{Design}

The design consists of led holder plate, excitation filter holding plate, sample plate, a plate with focus mechanism, specially designed lens holder plate, emission filter plate, camera plate and base plate. 
After the basic elements of the design were determined, it was decided to create the skeleton with 3mm PMMA, which was selected by considering factors such as the suitability of the price, ease of access etc. Special plates were prepared to hold the sample, filters, lens and light source to be imaged, and the mechanical part of the microscope was formed using a laser cutter. A commercially available Logitech C310 CAMERA (1280x720 Pixels) was used. The camera housing is removed and the CMOS sensor is exposed. Special plate design has been made by using aluminum material in appropriate dimensions for the lens to fit. The appropriate slot is added to the tooth pitch of the lens. The bottom layer is designed to be metal, considering it to be more robust. Metal plates designed in Bysoft drawing program were cut with Bystronic Sprint 4400 laser cutter.

A practical focus mechanism design was made which was created by the interwoven and threaded structure. With this specially developed design, it is aimed to ensure the movement and focus of the mechanism that holds the sample. The focal mechanism allows the sample holder plate to rise evenly in planar form, making it easier to achieve equilibrium. Thus, it creates ease of use.

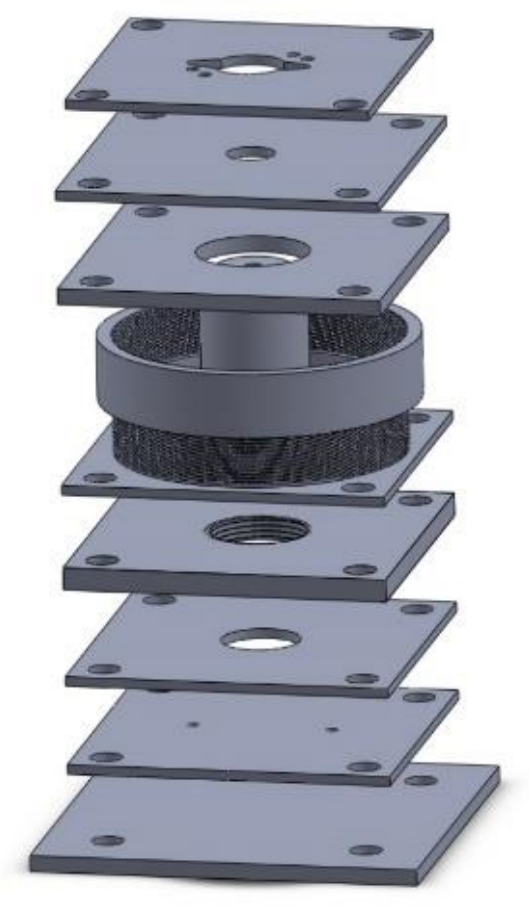

Figure 1. Schematic Design of the Mini Fluorescence Microscope

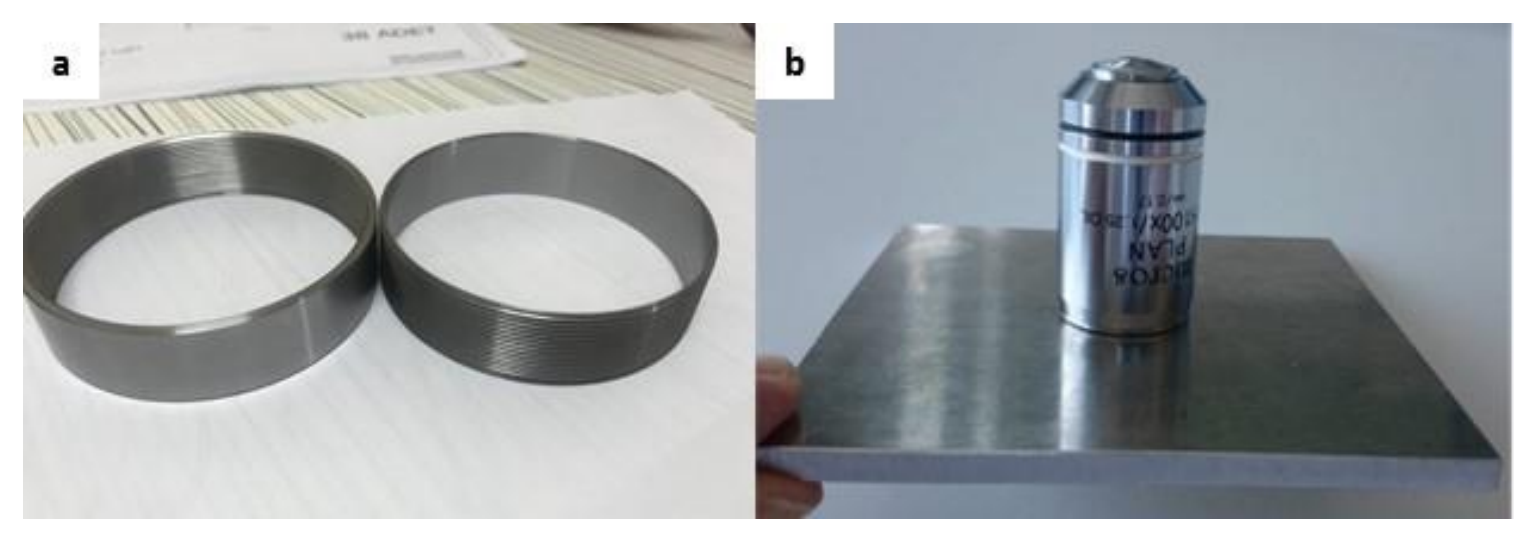

Figure 2. Design Ideas a) Practical Focus System b) Objective Holder

\subsection{Materials}

Fluorescent dyes are used to capture images when they meet light at the appropriate wavelength. When these dyes combine with tissues, they have the capacity to convert ultraviolet light into visible light. DAPI fluorescent dye was selected considering ease of use and accessibility (Rottenfusser, Wilson, \& Davidson). The DAPI fluorescent dye stains the nucleus of the cell, facilitating image acquisition from cells with nuclei. DAPI has an absorption (ultraviolet) at a maximum wavelength of $358 \mathrm{~nm}$ and its maximum emission is $461 \mathrm{~nm}$ (blue). Therefore, the appropriate emission and excitation filters for DAPI were determined by performing spectrophotometer tests.

With consideration of the DAPI fluorochrome spectrum viewer the filters to be used must be in the wavelength range of maximum $360 \mathrm{~nm}$ for the excitation filter and maximum $460 \mathrm{~nm}$ for the emission filter (BD Biosciences). 

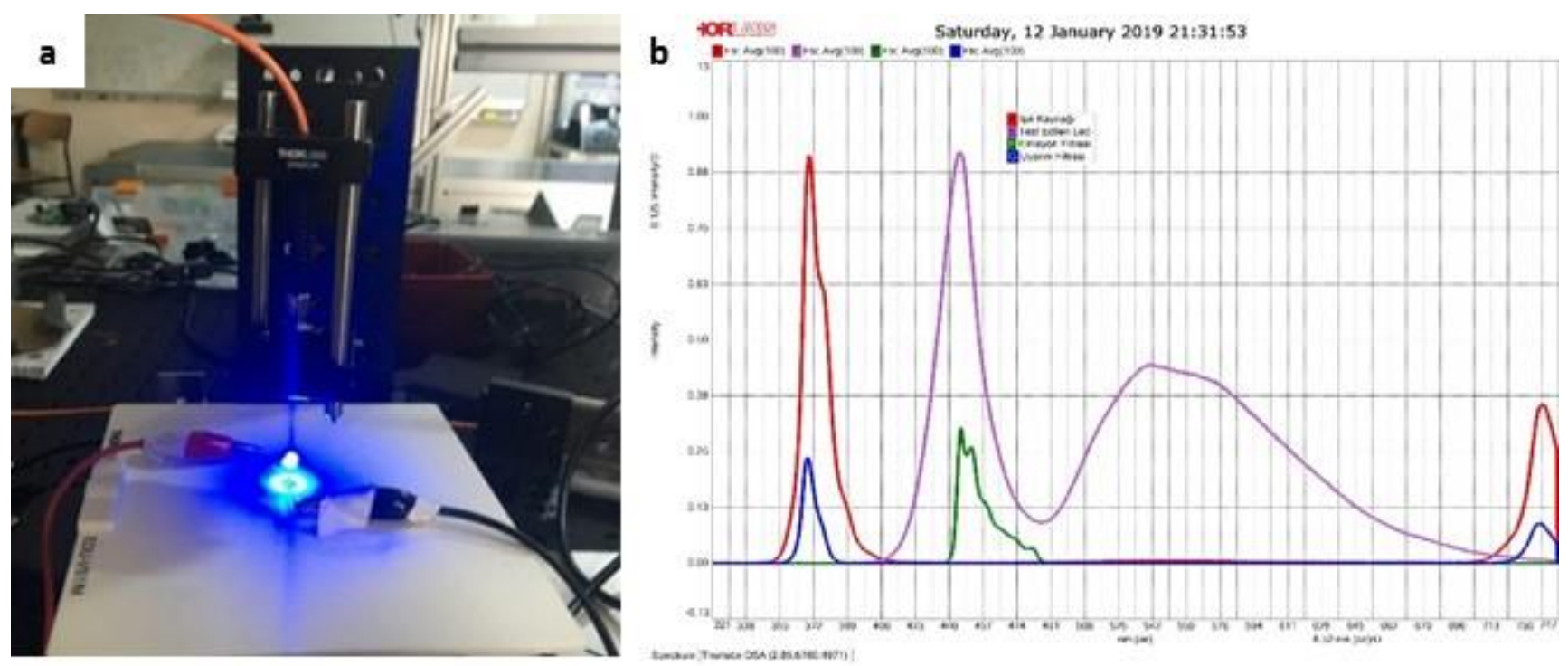

Figure 3. a) Test Mechanism of LEDs and Filters b) The Tested Optical Elements: Red Shows LED Light Sources, Blue Shows The Excitation Filter and Green Shows The Emission Filter

\subsection{Assembly}

The mechanical skeleton of the Mini fluorescent microscope is formed by 3 mm PMMA. Each designed part is drawn in the CorelDraw drawing program. The plates were cut with AEON laser cutter. Adjustments were made for the laser to complete the cut without leaving a shot mark and without any loss of power. The plates created with the laser cutter are combined to be layered from the bottom to up. The structure was supported by proper screws and nuts during the construction phase of the microscope skeleton.

It has been decided to use a cooler due to the problem of rapid heating of power LEDs in the long term. An LED cooler suitable for the design has been acquired. In order to mount the LED and to supply the required nests, it is mounted with screw, which has been opened.

The LED driver used in the design is the Thorlabs LEDD1B and an M8 4-pin connector was supplied to match this LED driver. The connection to the LED has been completed considering the datasheets of this cable (THORLABS, 2016).
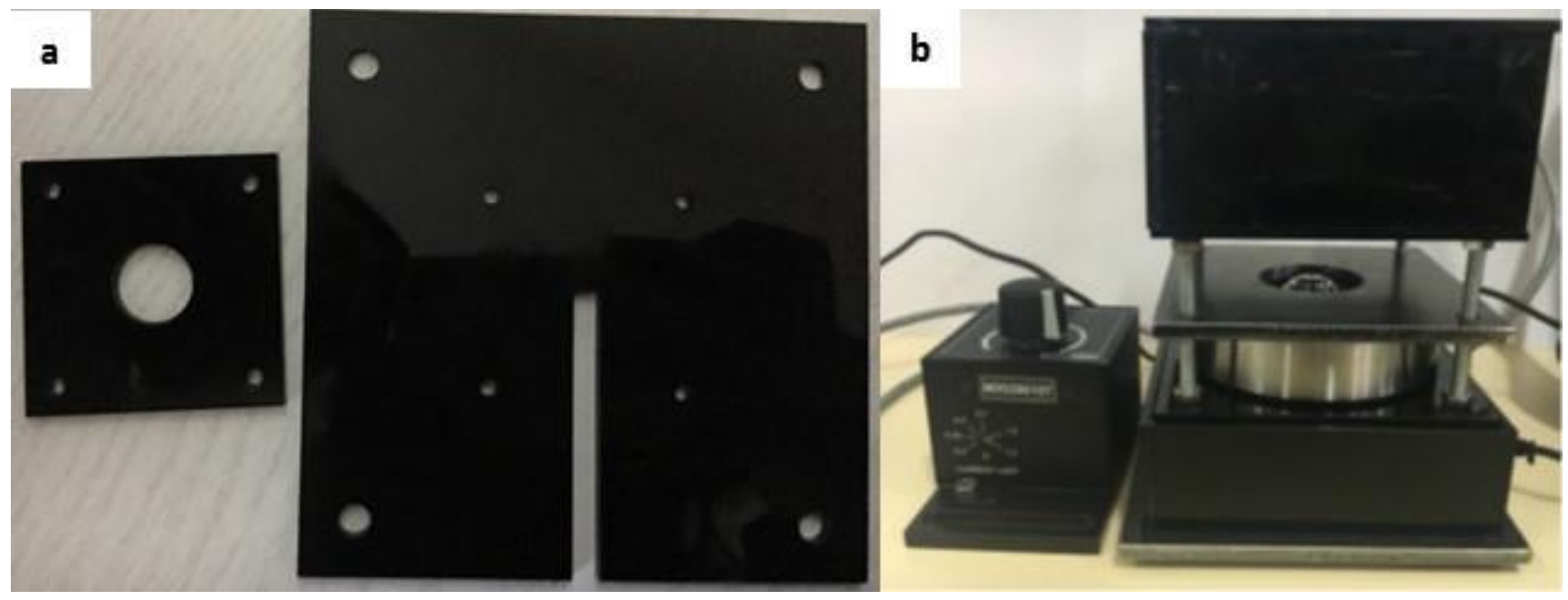

Figure 4. a) Microscope Plates Manufactured with Laser Cutter b) Manufactured Mini Fluorescence Microscope with LED Driver

The distance between the plates is determined according to the calculations regarding the position of the lens and the distance to the camera (Understanding Microscopes and Objectives). In order to adjust the balance of the plates, water level was used in each layer.

As a result of the calculations made on the mini fluorescent microscope, the distance between the lens and webcam sensor was 44 $\mathrm{mm}$, while the distance between the lens and the sample was found to be $4.4 \mathrm{~mm}$. The position of the lens in the microscope design was determined according to these results.

In the later stages of the design, a microscope chamber was designed using Plexiglas to minimize the image pollution caused by the cables and to ensure a more tidy appearance. 


\section{Results and Discussion}

\subsection{Characterization of Mini Fluorescence Microscope}

The mini fluorescent microscope has been specially designed using PMMA and metal structures to be cost effective, lightweight and portable. The produced microscope has a small form structure, so it is easily portable. Its dimensions are $120 \mathrm{~mm} \mathrm{x} 120 \mathrm{~mm} \mathrm{x}$ $170 \mathrm{~mm}, 2448 \mathrm{~cm}^{3}$ and weight is 1000 grams. The whole design cost $2500 \mathrm{TL}$ (434 USD). Its low cost enables researchers to produce more with minimum investment. The specially developed focus system makes it easy to adjust the focus. In addition, due to its modular structure, the light source and filter holders used in the design have been specially designed. If another fluorescent dye is used, it can be adapted to the microscope.

\subsubsection{Calibration of Mini Fluorescence Microscope}

When the cell images were taken, the first prototype was tested as a bright field microscope without using fluorescent filters. Microscope calibration slide (Figure 5, a) was used for the images. In the first image taken, the distance between the two smallest lines is $0.01 \mathrm{~mm}$ (Figure 5, b). As a result, the required magnification calculations were performed according to optical formulas. Optical magnification in the $0.01 \mathrm{~mm}$ division was found to be $0.27 \mathrm{um} /$ pixel. On a 4.7 -inch phone screen, this magnification was 150 times, while on a 15.6-inch computer screen it was 600 times.

In another image sample taken with a mini fluorescent microscope, a $0.15 \mathrm{~mm}$ diameter circle (Figure 5 , c) on the calibration slide was used. The optical magnification was confirmed to be $0.27 \mathrm{um} /$ pixel by repeating the above steps for this image.

Table 1. Optical Values of Calibration Slide Images Taken with a Mini Fluorescent Microscope

\begin{tabular}{l|c|c}
\hline Division & $\mathbf{0 . 1 5} \mathbf{~ m m}$ & $\mathbf{0 . 0 1} \mathbf{~ m m}$ \\
\hline Optical magnification (um/pixel) & $0.27 \mathrm{um} / \mathrm{pixel}$ & $0.27 \mathrm{um} / \mathrm{pixel}$ \\
\hline Magnification on a 4.7-inch screen & 165 & 150 \\
\hline Magnification on a 15.6-inch screen & 610 & 600 \\
\hline
\end{tabular}
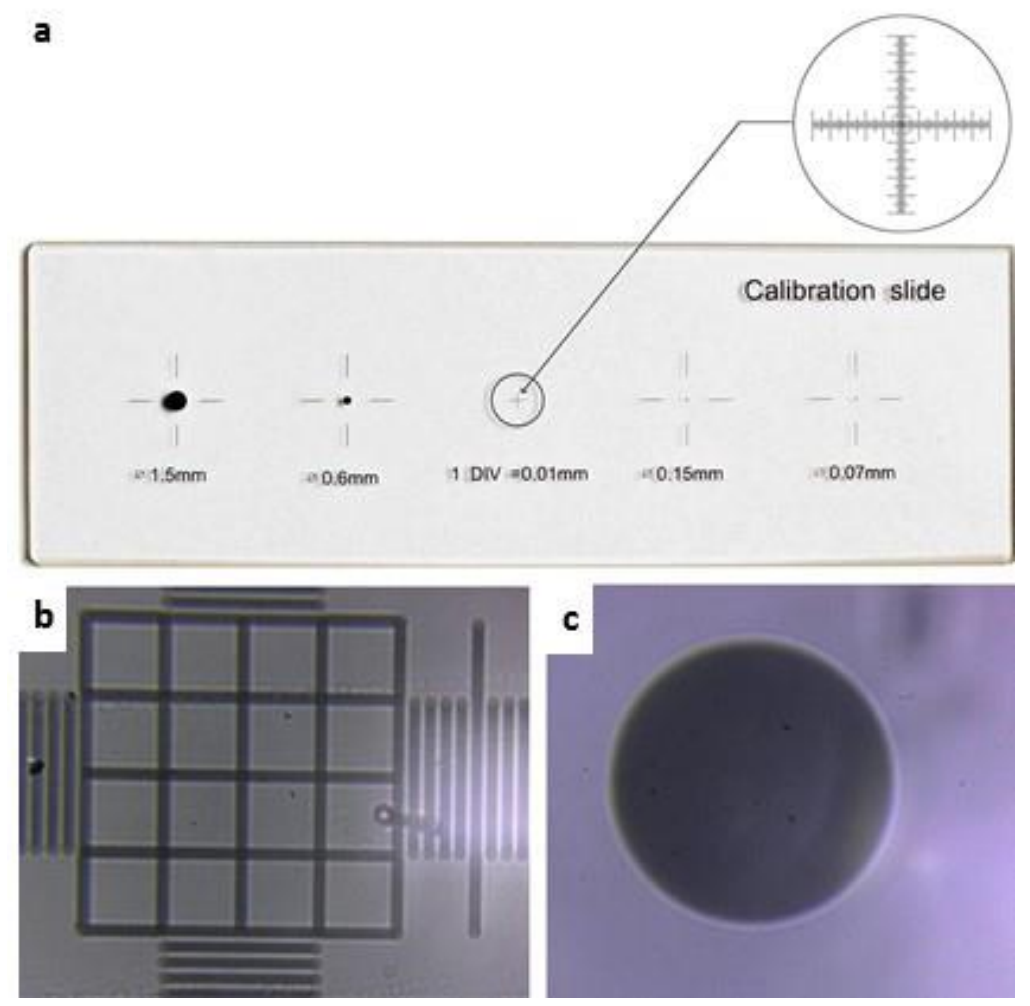

Figure 5. a) Microscope Calibration Slide b) $0.01 \mathrm{~mm}$ Division c) $0.15 \mathrm{~mm}$ Division

\subsection{Imaging of DAPI Fluorochrome}

Cells with nuclei were stained with DAPI fluorochrome and kept under appropriate conditions ( $4{ }^{\circ} \mathrm{C}$, no light, 24 hours) in order to obtain the image with the prototype formed. Then it was ready to take the image. As a result of these images, fluorescent dye sensitive to $360 \mathrm{~nm}$ wavelength was displayed and emission light emitted at $460 \mathrm{~nm}$ wavelength could be observed. 

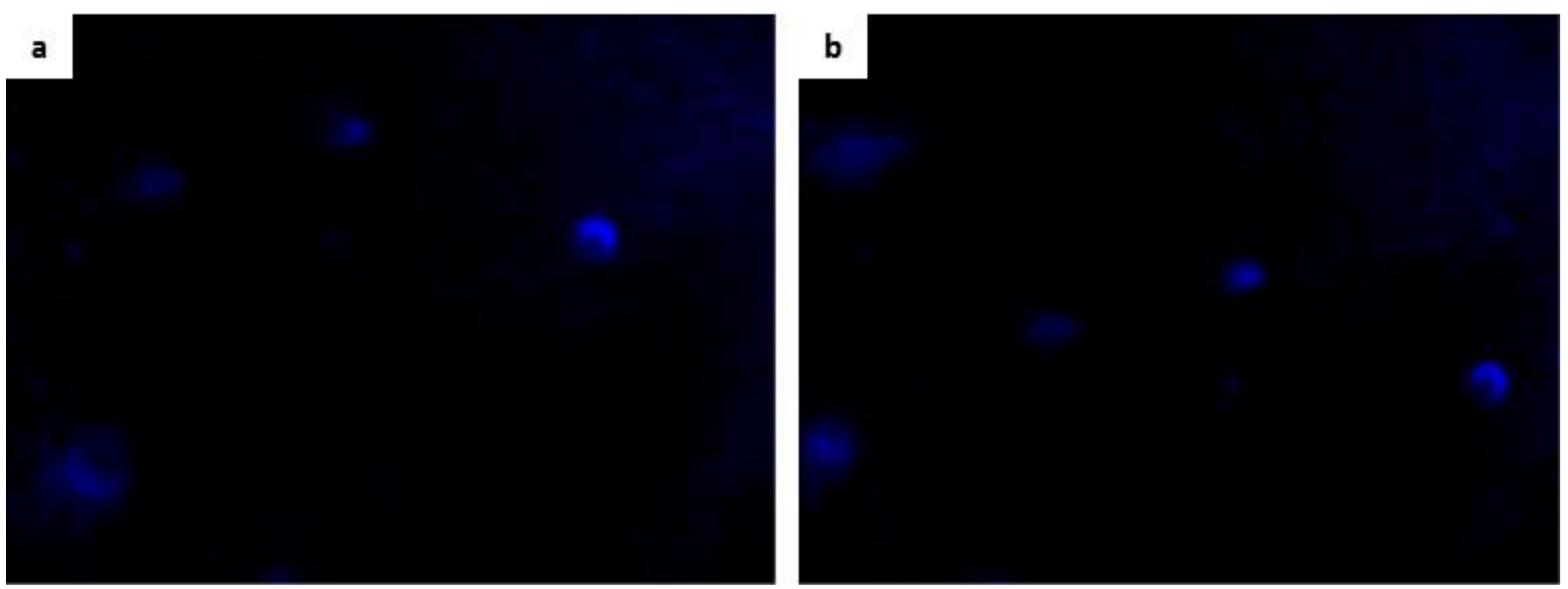

Figure 6. The image Obtained from the Mini-Microscope Showing Emitted Light at $460 \mathrm{~nm}$ and Illuminated with a Monochromatic LED at $360 \mathrm{~nm}$

\section{Conclusions and Recommendations}

Mini Fluorescence Microscope is a very useful device which can be developed in biology and medical laboratories and can be used everywhere and minimized the necessity of expert. In the analysis of a particular type of cell, a fluorescent microscope with a single focal point, stimulated by light at a single wavelength and detecting light at a single wavelength can be used. It is a small, practical and cost effective device since it can be a special purpose design.

The prototype consists of a mechanical part, an optical part and a camera. The design of the skeleton needed to carry the basic elements of the design was completed in the CorelDraw drawing program. After the decision of PMMA as suitable material for this design, microscope plates were formed by using laser cutter. The mechanical frame was completed by mounting these plates. Filters and light source were determined according to the fluorescent dye to be used in the optical part. These elements were tested with spectrophotometer device, and after it was decided that it was suitable for the design, they were assembled appropriately. The design was first tested as a bright field microscope and the optical magnification was found to be 0.27 um/pixel. The focal point of the microscope was calculated to be $4 \mathrm{~mm}$ and the focal length to be $44 \mathrm{~mm}$. With the microscope, the fluorescent particle was excited with light at $360 \mathrm{~nm}$ and the emission light emitted at $460 \mathrm{~nm}$ was displayed.

The portability, potential low cost and simple electronics requirements of the microscope are the main advantages. It requires minimal technical expertise with easy use. With these features, it is thought to be an alternative to traditional benchtop microscopes.

\section{References}

Zhang, Y. S., Ribas, J., Nadhman, A., Aleman, J., Selimović, Š., Lesher-Perez, S. C., ... Khademhosseini, A. (2015). A cost-effective fluorescence mini-microscope for biomedical applications. Lab on a Chip, 15(18), 3661-3669. https://doi.org/10.1039/c5lc00666j Kenneth R. Spring, \& Micheal W. Davidson. (2018). Introduction to Fluorescence Microscopy | MicroscopyU. from https://www.microscopyu.com/techniques/fluorescence/introduction-to-fluorescence-microscopy

Sanz, M., Picazo-Bueno, J. Á., Granero, L., Garciá, J., \& Micó, V. (2017). Compact, cost-effective and field-portable microscope prototype based on MISHELF microscopy. Scientific Reports, 7(February), 1-12. https://doi.org/10.1038/srep43291

Wei, Q., Qi, H., Luo, W., Tseng, D., Ki, S. J., Wan, Z., ... Ozcan, A. (2013). Fluorescent imaging of single nanoparticles and viruses on a smart phone. ACS Nano, 7(10), 9147-9155. https://doi.org/10.1021/nn4037706

spectrumviewer | BD Biosciences-US. (2018). from http://www.bdbiosciences.com/us/s/spectrumviewer

Understanding Microscopes and Objectives | Edmund Optics. (2019). from https://www.edmundoptics.com/resources/applicationnotes/microscopy/understanding-microscopes-and-objectives/

THORLABS. (2016). full-text. Retrieved from https://www.thorlabs.com/drawings/a88be2972f90488b-2FEDCBBD-0F3D-B6B6040F0B44DA00E73A/CAB-LEDD1-AutoCADPDF.pdf

Rottenfusser, R., Wilson, E. E., \& Davidson, M. W. (2019). ZEISS Microscopy Online Campus | Microscopy Basics | Fluorescence Microscopy. from http://zeiss-campus.magnet.fsu.edu/articles/basics/fluorescence.html 